\title{
60. THREE GABBROS FROM DSDP LEG 37, SITE 334: THEIR PETROGRAPHY AND PYROXENE MINERALOGY
}

\author{
R.E. Hill, Division of Mineralogy, CSIRO, Floreat Park, Western Australia
}

\section{INTRODUCTION}

Three samples of gabbro drilled from the ocean floor at Site 334 are described in this report. The sample identifications and exact positions in the core are listed in Table 1, together with the weights of the samples obtained and their specific gravities (S.G.).

Similar mineralogy characterizes the gabbros from Cores 21 and 23. These samples consist essentially of plagioclase feldspar, clinopyroxene, and orthopyroxene. Partial hydrothermal alteration of clinopyroxene to pale green actinolitic amphibole has occurred in Sample 23-1, 113-119 cm. The pyroxenes from both samples exhibit well-developed exsolution textures and have compositions (see later) indicative of relatively high temperatures of crystallization.

Late-stage magmatic green-brown hornblende, prehnite, chlorite, and tremolite characterize the heavily altered pyroxene- and plagioclase-bearing gabbro from Core 22, which, as a result, has a specific gravity lower than the other samples (Table 1).

TABLE 1

Sample Identification

\begin{tabular}{cclccc}
\hline Core & Section & $\begin{array}{c}\text { Sampled At } \\
(\mathrm{cm})\end{array}$ & Sample & $\begin{array}{c}\text { wt. } \\
(\mathrm{g})\end{array}$ & $\begin{array}{c}\text { S.G. } \\
(\mathrm{g} / \mathrm{cc})\end{array}$ \\
\hline 21 & 1 & $52-58$ & HI & 25.5 & 3.06 \\
22 & 1 & $5-6(\# 1)$ & HI & 12.8 & 2.84 \\
23 & 1 & $113-119(\# 12)$ & HI & 33.07 & 2.94 \\
\hline
\end{tabular}

Because detailed spatial, petrographic, and mineralogical relationships among the three gabbros are not known to this author, comparative petrological relationships cannot be discussed in detail. However, limited comparisons are made in an attempt to throw some light onto certain aspects of the crystallization histories of the rocks as reflected by the pyroxene phases. Also, comparisons are made between the pyroxenes from the Site 334 gabbros and those from similar rocks, particularly those from continental layered intrusives.

\section{PETROGRAPHY}

\section{Sample 21-1, 52-58 cm; Hypersthene Gabbro}

This rock is a coarse-grained holocrystalline gabbro with a hypidiomorphic granular texture and is composed essentially of plagioclase feldspar (38\%), orthopyroxene $(22 \%)$, and clinopyroxene $(40 \%)$.

Plagioclase feldspar occurs as subhedral to anhedral tabular to equant crystals up to $3 \mathrm{~mm}$ in size. Complex albite, Carlsbad, and pericline twinning are ubiquitous. The crystals are strained as evidenced by shadowy extinction and by distorted and fractured twin lamellae. They are subtly normally zoned with compositions ranging from Anss to Anso (electron microprobe).

Bronzite orthopyroxene is present as subhedral to anhedral grains with a maximum size of $4 \mathrm{~mm}$. The crystals exhibit faint pleochroism from pale pink to green and are moderately cleaved and fractured. They commonly include small subhedra of twinned plagioclase and partly mantle grains of clinopyroxene (Plate 1, Figure 1). Extremely fine, closely spaced exsolution lamellae of the Bushveld type, parallel to (100) of the host are observable in thin section in grains of suitable orientation. In other grains this exsolution is observed as a fine diffuse lamellar texture parallel to (100) when viewed under crossed nicols, particularly near extinction.

Augitic clinopyroxene, with an average size of $4 \mathrm{~mm}$, generally closely resembles orthopyroxene in its morphology. It also occurs as subordinate large tabular subhedral phenocrysts up to $1 \mathrm{~cm}$ long. All grains contain exsolution lamellae of $\mathrm{Ca}$-poor pyroxene aligned parallel to (100) and (001) (Plate 1, Figure 2). The (001) lamellae are larger, reaching $5 \mu \mathrm{m}$ in width. The (100) lamellae predominate and are extremely fine and closely spaced. The crystals are well cleaved and are commonly twinned about the (100) plane (Plate 1, Figure 3 ). The compositions of both pyroxenes are listed in Table 2 and discussed later in this report.

\section{Sample 22-1, 5-6 cm; Hydrothermally Altered Hornblende Gabbro}

The rock is an extensively altered, coarse-grained, hornblende gabbro consisting of plagioclase, clinopyroxene, amphibole, chlorite, and prehnite. It exhibits a pronounced cataclastic texture.

The plagioclase feldspar is present as large (up to 1 $\mathrm{cm})$ fractured subhedral to anhedral crystals, with abraded and sutured margins. The crystals exhibit evidence of extensive strain, being characterized by pronounced undulatory extinctions and bent and fractured twin lamellae. Twinning is not ubiquitous but, where present, is quite complex. Smaller twinned anhedra of plagioclase occur as granular mosaics in the interstices between larger abraded feldspars, together with grains of altered clinopyroxene and blocky secondary amphibole (Plate 1, Figure 4). The large feldspar crystals commonly contain many trains of fluid inclusions and are often associated with and partly altered to fine-grained prehnite.

Clinopyroxene, containing visible exsolution lamellae of Ca-poor pyroxene aligned parallel to the 
(100) plane, occurs as ragged anhedral remnants up to 1 $\mathrm{cm}$ long and is extensively replaced by a mixture of pale green pleochroic, fibrous amphibole and darker greenbrown chlorite. The heavily altered clinopyroxene is commonly mantled by pleochroic dark green-brown, late magmatic hornblende which also occurs as finer grained blocky, occasionally twinned, subhedra filling fractures and occurring in the interstices between the coarser crystalline phases. Some anhedral felted masses of very pale green fibrous amphibole are thought to be pseudomorphous after primary orthopyroxene, although no fresh orthopyroxene was observed in thin section.

Prehnitization has been extensive. Veins of prehnite up to $0.3 \mathrm{~mm}$ in diameter cut all other minerals, and large patches, presumably once feldspar, are now occupied by an equigranular mosaic of this prehnite. The prehnite is commonly accompanied by brownish nonpleochroic chlorite. Very fine grained acicular tremolite (X-ray identification) also occurs as a secondary phase, filling vugs within fractures accompanying the chlorite and prehnite.

\section{Sample 23-1, 113-119 cm; Hypersthene Gabbro}

The rock is a coarse-grained holocrystalline gabbro with hypidiomorphic granular texture consisting of plagioclase feldspar (52\%), clinopyroxene $(20 \%)$, orthopyroxene $(20 \%)$, and amphibole $(8 \%)$.

The plagioclase feldspar occurs as subhedral to anhedral crystals up to $3 \mathrm{~mm}$ in size. The crystals are very slightly normally zoned with compositions ranging from $A_{n_{78}}$ to $A_{75}$ (electron microprobe). They exhibit complex twinning and are characterized by sutured and abraded grain boundaries, bent and fractured twin lamellae, and stress-induced undulatory extinction.

Hypersthene is present as large anhedral crystals up to $6 \mathrm{~mm}$ across, slightly pleochroic from pale pink to green. Both Bushveld and Stillwater types of exsolution of clinopyroxene are ubiquitous. Very fine, closely spaced exsolution lamellae of the Bushveld type occur aligned in planes parallel to the (100) plane of the host, and more primitive widely spaced vermiform stringers and patches of Stillwater-type clinopyroxene up to $20 \mu \mathrm{m}$ wide are crudely aligned parallel to (001) in some crystals, and in others are seemingly random (Plate 2, Figures, 1, 2). Cataclastic abrasion of the crystals is evidenced in places by their irregular margins. Limonite staining is visible on fractures which traverse the crystals.

Clinopyroxene occurs as culorless subhedral to anhedral crystals up to $8 \mathrm{~mm}$ across. The crystals contain abundant exsolution lamellae of $\mathrm{Ca}$-poor pyroxene aligned in two directions, the most common being up to $15 \mu \mathrm{m}$ wide, paralleling the (001) plane of the host (Plate 2, Figures 1, 2). Some crystals include small subhedral to euhedral grains of plagioclase feldspar.

Augitic clinopyroxene crystals are irregularly mantled and sometimes completely replaced by a pale green pleochroic actinolitic amphibole. These deuteric overgrowths of amphibole extend into fractures as vein fillings and cut across all other phases.
The chemical compositions of the pyroxenes are listed in Table 2.

\section{CHEMICAL STUDY OF PYROXENES}

Reliable quantitative electron microprobe analyses of the pyroxene phases have been obtained from the relatively fresh gabbros from Cores 21 and 23 . Particular grains were selected for analyses on the basis of orientation, size of lamellae, and freedom from incipient alteration and fractures.

Where possible, both host and lamellae have been analyzed using a stationary focused electron beam. The bulk compositons of the grains were determined using a rastered focused beam.

The analysis of exsolution lamellae has been restricted to those lamellae paralleling the basal plane of the host phases, i.e. (001), since these lamellae were by far the larger of the two varieties in all crystals. Analyses reported herein are from lamellae over $10 \mu \mathrm{m}$ wide in order to overcome phase boundary fluorescence effects which are particularly significantly for the analysis for calcium in hypersthene lamellae (Reed and Long, 1963; Binns, et al., 1963; Boyd and Brown, 1969). No attempt has been made to correct for this effect in this study, and as a result the calcium contents presented herein may be slightly high $(\sim 0.1 \mathrm{wt} \% \mathrm{Ca})$.

The electron microprobe used was a M.A.C. 400 S model with a takeoff angle of $38.5^{\circ}$. The instrument was operated at $19.3 \mathrm{kv}$ with sample currents of around $10 \mathrm{nA}$ for all analyses. Scalers were operated in the fixed-time mode, counts being made over a period of 20 sec. Metal standards were used for all elements except aluminum, magnesium, and calcium. For these, $\mathrm{Al}_{2} \mathrm{O}_{3}$, $\mathrm{MgO}$, and apatite, respectively, were used as standards. The data were corrected using the computer program, MAGIC IV, of Colby (1971).

The analytical data, together with calculated formulas (cations per six oxygens) are listed in Tables 2 and 3 . The compositions of coexisting phases are portrayed in Figure 1.

Both the Ca-rich and Ca-poor pyroxenes in the sample from Core 21, Section 1, are more magnesian than their counterparts from Core 23, Section 1. This limits deductions concerning the petrologic and genetic relationships between the two gabbros, suggesting that the gabbro from Core 21 may be the earlier differentiate. This also suggested by the higher anorthite content of the plagioclase feldspar in the former sample (An ${ }_{85}-90$ compared to $A_{75}-78$ ).

As expected, the Ca-poor pyroxenes have higher $\mathrm{Fe} / \mathrm{Mg}$ ratios and lower contents of alumina and titania than the coexisting $\mathrm{Ca}$-rich pyroxenes (Tables 2 and 3).

The Ca-rich pyroxenes from both gabbros are augites similar in composition to those from a porphyritic olivine gabbro in Hawaii (Muir and Tilley, 1957) and to the high-temperature, first-pyroxene separates from the Lower Layered Series of the Jimberlana Dyke (Campbell and Borley, 1974). However, the analyzed pyroxenes contain less calcium than pyroxenes with a 
TABLE 2

Electron Microprobe Analyses ${ }^{\mathrm{a}}$ and Ionic Formulas

\begin{tabular}{lcrcr}
\hline & \multicolumn{2}{c}{ Orthopyroxene } & \multicolumn{2}{c}{ Clinopyroxene } \\
& \multicolumn{1}{c}{ Bulk } & Host & Bulk & Host \\
\hline $\mathrm{SiO}_{2}$ & 54.67 & 54.97 & 52.71 & 51.73 \\
$\mathrm{Al}_{2} \mathrm{O}_{3}$ & 1.36 & 1.41 & 2.34 & 2.56 \\
$\mathrm{TiO}_{2}$ & 0.11 & 0.08 & 0.15 & 0.37 \\
$\mathrm{FeO}$ & 13.12 & 13.22 & 7.55 & 6.02 \\
$\mathrm{MgO}$ & 28.38 & 27.85 & 18.02 & 15.87 \\
$\mathrm{CaO}$ & 2.35 & 2.36 & 19.23 & 22.88 \\
$\mathrm{CoO}$ & - & 0.08 & - & 0.28 \\
$\mathrm{NiO}$ & - & 0.04 & - & 0.28
\end{tabular}

Ionic Formula per Six Oxygens

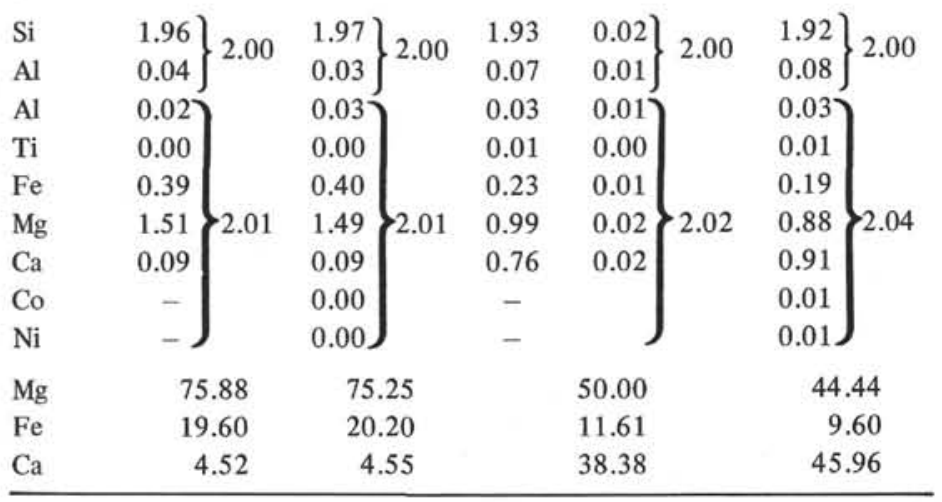

\begin{abstract}
${ }^{a}$ Expressed as normalized weight percent oxide. Data are for the bulk orthopyroxene and clinopyroxene phases and the host components from the Core 21, Section 1 gabbro sampled at $52-58 \mathrm{~cm}$. Atomic proportions of $\mathrm{Mg}, \mathrm{Fe}$, and $\mathrm{Ca}$ normalized to $100 \%$ are also presented. Bulk compositions were determined using a focused electron beam rastered over an area $100 \mu \mathrm{m}$ square. Standard deviations, S. are presented with selected ionic formulas.
\end{abstract}

similar $\mathrm{Mg} / \mathrm{Fe}$ ratio from the Bushveld (Atkins, 1969) and Skaergaard (Brown, 1957) magmas (Figure 1).

The Ca-poor pyroxene from Core 21, Section 1 is bronzite and that from the Core 23 gabbro is pigeonite (Tables 3 and 4). The bronzite is similar in composition to the Hawaiian and Jimberlana orthopyroxenes. The pigeonite is similar in composition to the first pigeonite deduced to have crystallized from the Jimberlana Dyke, but is higher in both magnesium and calcium than published analyses and compositional estimates of the first pigeonite to crystallize after the cessation of bronzite in other layered intrusions (Figure 1).

The high magnesium content of the pigeonite indicates a relatively high temperature of crystallization for the Site 334 gabbros. Compatible with this are the relatively high calcium content of the bronzite and the low calcium content in the clinopyroxenes or more specifically, the narrow subsolidus miscibility gap as exhibited by the coexisting bulk compositions in Figure 1 .

The subsolidus exsolution textures displayed in the pyroxenes from each rock are summarized below.

'(001) lamellae and (100) lamellae are the terminologies used herein to describe lamellae essentially parallel to the (001) and (100) planes of the host phase. Detailed crystallographic orientations have not been carried out to ascertain the exact crystallographic orientations.
1) Core 21, Section 1: augite containing $(001)^{1}$ and (100)' lamellae + bronzite containing (100) lamellae.

2) Core 23, Section 1: augite containing (001) and (100) lamellae + inverted pigeonite containing (001) and (100) lamellae.

The presence of basal plane (001) exsolution lamellae in both of the Mg-rich augites suggests that these lamellae exsolved as the monoclinic phase pigeonite, and that crystallization of these pyroxenes took place above the monoclinic-orthorhombic inversion curve (Poldervaart and Hess, 1951; Hess, 1960). A corollary to this is that the expected Ca-poor pyroxene crystallizing in conjunction with the augites should also be pigeonitic.

These conclusions are not negated by the augitepigeonite pair of the Core 23 gabbro. As implied, subsolidus cooling of the Core 23 gabbro has resulted in the inversion of the pigeonitic Ca-poor pyroxene to orthorhombic hypersthene with concomitant exsolution and a decrease in its calcium content (Figure 1). The basal-plane exsolution lamellae are of high-calcium augite similar in composition to the host component of the Ca-rich pyroxene. The (001) lamellae exsolved from the Ca-rich pyroxene are hypersthene with a composition slightly more iron rich than the host of the Ca-poor phase (Figure 1, Table 3). 


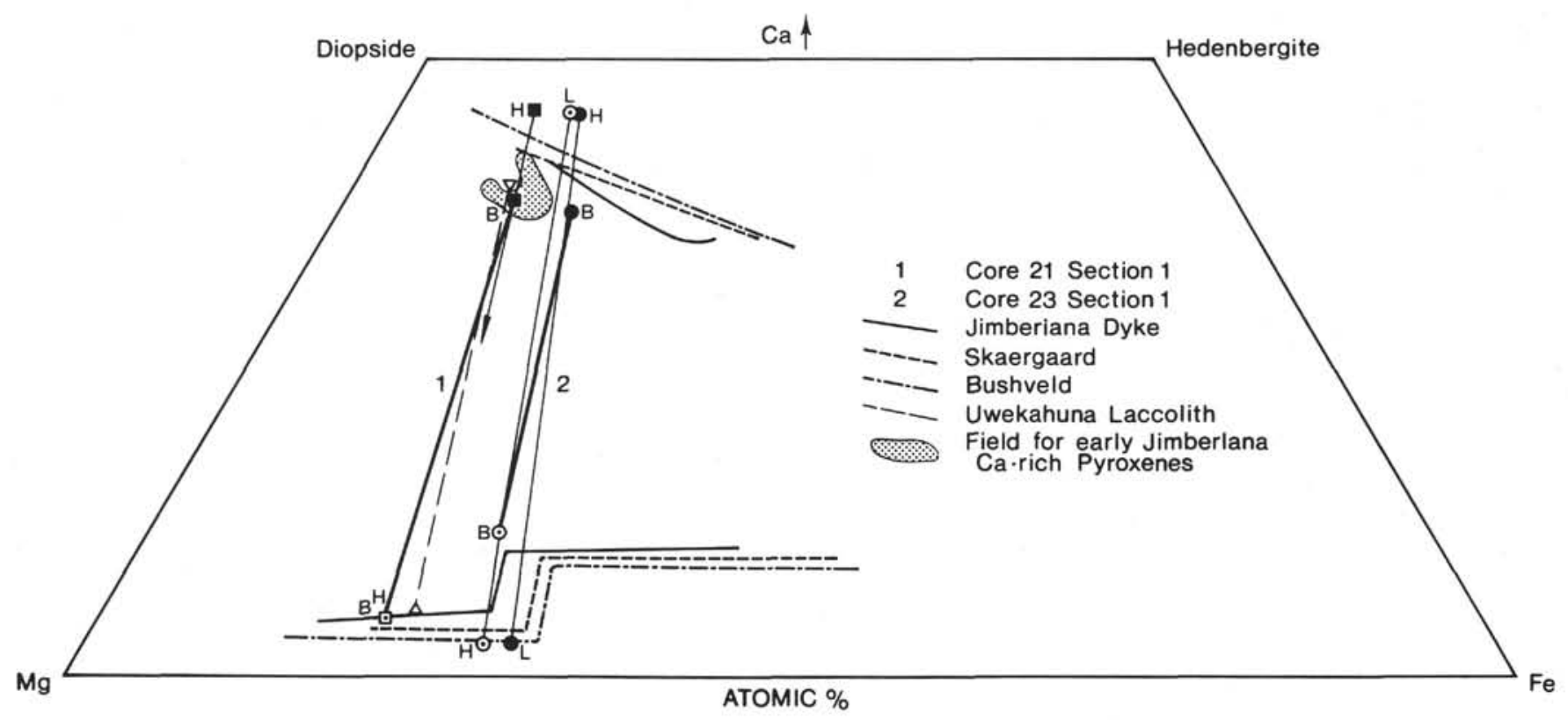

Figure 1. The coexisting Ca-rich and Ca-poor pyroxenes from the gabbros of Core 21, Section 1, 52-58 cm and Core 23, Section 1, 113-119 cm, plotted on the pyroxene quadrilateral. Compositions are plotted of bulk pyroxenes $B$, hosts $H$, and included lamellae L. Plotted for comparison are the early pyroxene trends from the Jimberlana (Campbell and Borley, 1974); Skaergaard (Brown, 1957); and Bushveld (Atkins, 1969) intrusions. Coexisting Ca-rich and Ca-poor pyroxenes from the “porphyritic gabbro," Uwekahuna Laccolith, Kilauea (Muir and Tilley, 1957) are also plotted.

Similar subsolidus cooling relationships were presented by Boyd et al. (1969) in their study of the compositions of the hosts and lamellae comprising coexisting pyroxenes richer in iron from the Bushveld Intrusion. These authors confirmed previous studies including those of Bown and Gay (1960) and Binns et al. (1963) that the exsolution lamellae aligned parallel to (001) in the Ca-rich pyroxene are now clinohypersthene not orthorhombic hypersthene (inverted pigeonite) as was previously expected, Poldervaart and Hess (1951). The consistently low calcium content of all analyzed lamellae parallel to (001) of the augites from the Core 23, Section 1 gabbro (Table 3) and the lack of detectable secondary exsolution within the lamellae suggest strongly that the lamellae may also be clinohypersthene which have failed to invert to the orthorhombic phase because of structural constraints imposed by the host augite. These lamellae would have maintained compositional equilibrium with the host down to relatively low temperatures by ease of ionic migration.

In contrast to the Core 23 pyroxenes, those from the Core 21 gabbro are somewhat enigmatic. No other examples of truly igneous Ca-rich pyroxenes of this composition which contain basal plane exsolution lamellae are known to the author, including those from the compositionally compatible Jimberlana Dyke. All other crystals are believed to have exsolved orthopyroxene only, paralleling or closely paralleling the (100) crystallographic direction, a feature compatible with crystallization below the clinopyroxene-orthopyroxene inversion loop. The coexisting Ca-poor pyroxene from Core 21 is an orthorhombic bronzite containing only (100) exsolution lamellae, and there is no evidence to suggest that it was at any stage a pigeonite. The compositional relationships between the $\mathrm{Ca}$-rich pyroxene and its host component are similar to those of the Core 23 gabbro. Although the basal plane exsolution lamellae are too narrow to provide reliable analyses, a point on the extension of the tie-line joining host and bulk compositions towards the expected compositions of the exsolved phase lies to the iron side of the coexisting orthopyroxene-bulk clinopyroxene join, also similar to the Core 23 gabbro (Figure 1). It is possible that these exsolution lamellae, like those in the Core 23 gabbro, are monoclinic.

The orthorhombic bronzite contains many fine, closely spaced (100) exsolution lamellae visible only in sections parallel to $(010)$ of the host. There are too many lamellae for all of these to be diopsidic augite in composition, since the bronzite contains only $2.35 \mathrm{wt} \%$ $\mathrm{CaO}$, (Table 1). Also, the average compositions of the host component are almost identical to bulk compositions, perhaps a function of the closeness of the exsolution lamellae. It is suggested that the observed exsolution texture may be the result of some subtle calcium redistribution during structural adjustments of the Ca-poor pyroxene on cooling.

Coexisting Mg-rich metamorphosed pyroxenes from the core of an ultramafic inclusion in the Belchertown Complex, Massachusetts, comprise Ca-rich augites which contain, as well as others, basal-plane lamellae of clinopyroxene, and $\mathrm{Ca}$-poor orthorhombic bronzites similar to those from the Core 21 gabbro, Jaffe et al. (1975). Jaffe et al. suggest two possible explanations for this enigmatic relationship:

1) Under conditions where orthorhombic pyroxene is stable, metastable monoclinic lamellae can nucleate in augite; and

2) Monoclinic lamellae are stable again at lower temperatures. They favor the former explanation on structural grounds for the Belchertown pyroxenes, and 
this is a not unlikely reason for the Core 21 pyroxenes as well.

The subtle noncolinearity of the bulk, host, and lamellae compositions for the coexisting pyroxenes from each rock, as plotted in Figure 1, may in part be due to uncertainties in the microprobe analyses, but may also suggest that interphase equilibration ceased at some temperature after crystallization and that each phase subsequently acted essentially as a closed system in which intraphase exsolution and equilibration was maintained to lower temperatures. To what extent each of these factors contributes to the noncolinearity is not known. The presence of extensive exsolution, a product of slow cooling, doubtless suggests that at least some postcrystallization subsolidus interphase reequilibration must have occurred. However, for example, the differences in slope in Figure 1 between the tie-line joining the bulk compositions of the pyroxenes in the Core 23 gabbro and those joining the respective host and lamellae components may reflect to some degree the temperature interval between the cessation of interphase subsolidus equilibration and the cessation of exsolution at lower temperatures. If this be so, concomitant changes in the distribution of iron and magnesium between the two pyroxenes must be indicative of a temperature drop.
The simple ideal formula for the distribution coefficient $K_{D}$ (Kretz, 1963) where

$$
\mathrm{K}_{\mathrm{D}} \underset{(\mathrm{Mg}-\mathrm{Fe})}{\text { Ca-poor/Ca-rich }} \frac{\mathrm{X}_{\mathrm{MgSiO}_{3}}}{1-\mathrm{X}_{\mathrm{MgSiO}_{3}}} \cdot \frac{1-\mathrm{X}_{\mathrm{MgCaSi}_{2} \mathrm{O}_{6}}}{\mathrm{X}_{\mathrm{MgCaSi}_{2} \mathrm{O}_{6}}}
$$

and $\mathrm{XMgSiO}_{3}$ and $\mathrm{XMgCaSi}_{2} \mathrm{O}_{6}$ are mole fractions, has been used to produce the coefficients listed in Table 4.

The data listed in Table 4 are consistent with the above discussion. The average value of $K_{D}$ around 0.90 for the bulk pyroxenes is indicative of a high temperature of equilibration. The lower values averaging around 0.69 for the host-lamellae pairs from both rocks are compatible with relatively low temperatures of equilibration. The value of 0.69 for the Core 21 gabbro was determined using the compositions of the host component of the Ca-rich pyroxene and that of theoretical hypersthene lamellae containing a similar calcium content to the coexisting bronzite but lying on the extension of the line joining the host and bulk $\mathrm{Ca}-$ rich pyroxene compositions (Figure 1).

The value of $K_{D}$ around 0.69 for the host-lamellae components is consistent with that determined ex-

TABLE 3

Electron Microprobe Analyses ${ }^{\mathrm{a}}$ and Ionic Formulas

\begin{tabular}{lcrrrrr}
\hline & \multicolumn{2}{c}{ Orthopyroxene } & \multicolumn{3}{c}{ Clinopyroxene } \\
& \multicolumn{1}{c}{ Bulk } & Host & Lamellae & $\begin{array}{r}\text { Bulk } \\
\text { Bomellae }\end{array}$ & $\begin{array}{c}\text { Host } \\
\text { Clinohypersthene }\end{array}$ \\
\hline $\mathrm{SiO}_{2}$ & 53.05 & 53.93 & 52.14 & 51.76 & 51.49 & 53.72 \\
$\mathrm{Al}_{2} \mathrm{O}_{3}$ & 1.69 & 0.96 & 1.54 & 2.54 & 1.91 & 0.90 \\
$\mathrm{TiO}_{2}$ & 0.22 & 0.23 & 0.37 & 0.23 & 0.41 & 0.15 \\
$\mathrm{FeO}$ & 15.83 & 17.89 & 7.83 & 10.15 & 7.87 & 19.19 \\
$\mathrm{MgO}$ & 23.40 & 25.66 & 15.28 & 16.74 & 15.50 & 24.78 \\
$\mathrm{CaO}$ & 5.80 & 1.19 & 22.70 & 18.58 & 22.82 & 1.18 \\
$\mathrm{CoO}$ & - & 0.07 & 0.07 & - & 0.00 & 0.04 \\
$\mathrm{NiO}$ & - & 0.07 & 0.07 & - & 0.00 & 0.04
\end{tabular}

Ionic Formula per Six Oxygens

\begin{tabular}{|c|c|c|c|c|c|c|c|c|c|c|c|c|c|}
\hline $\begin{array}{l}\mathrm{Si} \\
\mathrm{Al}\end{array}$ & $\left.\begin{array}{l}1.94 \\
0.06\end{array}\right\}$ & 2.00 & $\begin{array}{l}1.97 \\
0.03\end{array}$ & 2.00 & $\begin{array}{l}1.94 \\
0.06\end{array}$ & $\left.\begin{array}{l}0.01 \\
0.01\end{array}\right\}$ & 2.00 & $\begin{array}{l}1.92 \\
0.08\end{array}$ & 2.00 & $\begin{array}{l}1.92 \\
0.08\end{array}$ & 2.00 & $\left.\begin{array}{l}1.97 \\
0.03\end{array}\right\}$ & 2.00 \\
\hline $\mathrm{Al}$ & 0.017 & & 0.017 & & 0.01 & 0.017 & & $0.03^{\prime}$ & & 0.007 & & 0.01 & \\
\hline $\mathrm{Ti}$ & 0.01 & & 0.01 & & 0.01 & 0.00 & & 0.01 & & 0.01 & & 0.00 & \\
\hline $\mathrm{Fe}$ & 0.48 & & 0.55 & & 0.24 & 0.01 & & 0.32 & & 0.25 & & 0.59 & \\
\hline $\mathrm{Mg}$ & 1.28 & 2.01 & 1.40 & 2.02 & 0.85 & 0.01 & 2.02 & 0.93 & 2.03 & 0.86 & 2.03 & 1.36 & 2.01 \\
\hline $\mathrm{Ca}$ & 0.23 & & 0.05 & & 0.91 & 0.01 & & 0.74 & & 0.91 & & 0.05 & \\
\hline Co & - & & 0.00 & & 0.00 & 0.00 & & - & & 0.00 & & 0.00 & \\
\hline $\mathrm{Ni}$ & $-J$ & & 0.00 & & 0.00 & 0.00 & & - & & 0.00 & & 0.00 & \\
\hline $\mathrm{Mg}$ & \multicolumn{2}{|c|}{64.32} & \multicolumn{2}{|c|}{70.00} & \multicolumn{3}{|c|}{42.50} & \multicolumn{2}{|c|}{46.73} & \multicolumn{2}{|c|}{42.57} & \multicolumn{2}{|c|}{68.00} \\
\hline $\mathrm{Fe}$ & \multicolumn{2}{|c|}{24.12} & \multicolumn{2}{|c|}{27.50} & \multicolumn{3}{|c|}{12.00} & \multicolumn{2}{|c|}{16.08} & \multicolumn{2}{|c|}{12.38} & \multicolumn{2}{|c|}{29.50} \\
\hline $\mathrm{Ca}$ & \multicolumn{2}{|c|}{11.56} & \multicolumn{2}{|c|}{2.50} & \multicolumn{3}{|c|}{45.50} & \multicolumn{2}{|c|}{37.19} & \multicolumn{2}{|c|}{45.05} & \multicolumn{2}{|c|}{2.50} \\
\hline
\end{tabular}

${ }^{a}$ Expressed as normalized weight percent oxide. Data are for the bulk Ca-poor and Ca-rich pyroxenes and their host and lamellae components from the Core 23, Section 1 gabbro sampled at $113-119 \mathrm{~cm}$. Atomic proportions of $\mathrm{Mg}, \mathrm{Fe}$, and $\mathrm{Ca}$ normalized to $100 \%$ are also presented. Bulk compositions were determined using a focused electron beam rastered over an area $140 \mu \mathrm{m}$ square. Standard deviations, S, are presented with selected ionic formulas. 
TABLE 4

Distribution Coefficients $K_{D}$ of $\mathrm{Fe}$ and $\mathrm{Mg}$ in

Coexisting $\mathrm{Ca}$-Rich and Ca-Poor Pyroxenes

\begin{tabular}{clc}
\hline Sample & \multicolumn{1}{c}{ Coexisting Pair } & $K_{D}$ \\
\hline Core 21, Section 1 & $\begin{array}{l}\text { Bulk clinopyroxene } \\
\text { Bulk orthopyroxene } \\
\text { Clinopyroxene host } \\
\text { Theoretical hypersthene lamellae }\end{array}$ & 0.90 \\
& $\begin{array}{l}\text { Bulk clinopyroxene } \\
\text { Bulk pigeonite } \\
\text { Clinopyroxene host }\end{array}$ & 0.92 \\
& $\begin{array}{l}\text { Hypersthene lamellae } \\
\text { Orthopyroxene host } \\
\text { Augite lamellae }\end{array}$ & 0.67 \\
\hline
\end{tabular}

perimentally by Lindsley et al. (1974) for coexisting Ca$\mathrm{Mg}-\mathrm{Fe}$ pyroxenes at $810^{\circ} \mathrm{C}$. The compositions of the host augites from both gabbros lie to the calcium-rich or lower temperature side of the $810^{\circ} \mathrm{C}$ isotherm on the pyroxene solvus as determined by these authors. The data suggest, however, that exsolution continued down to at least $800^{\circ} \mathrm{C}$. A more specific temperature for the cessation of exsolution and indeed an approximate figure for the crystallization of the pyroxene cannot be suggested since variables such as pressure and composition (including magma) have not been taken into account and there are still marked discrepancies between data from natural pyroxenes and phase relation studies.

There is little doubt, however, that the Site 334 gabbros crystallized at high temperatures and underwent a slow cooling which was continued to relatively low temperatures with continued extensive subsolidus exsolution and intraphase equilibration.

\section{REFERENCES}

Atkins, F.B., 1969. Pyroxenes of the Bushveld Intrusion, South Africa: J. Petrol., v. 10, p. 222-249.
Binns, R.A., Long, J.V.P., and Reed, S.J.B., 1963. Some naturally occurring members of the clinoenstatite-clinoferrosilite mineral series: Nature, v. 198, p. 777-778.

Bown, M.G. and Gay, P., 1960. An X-ray study of exsolution phenomena in the Skaergaard pyroxenes: Mineral. Mag., v. 32 , p. $379-388$.

Boyd, F.R. and Brown, G.M., 1969. Electron-probe study of exsolution in pyroxenes: Carnegie Inst. Wash. Yearbook, v. 66, p. $353-359$.

Brown, G.M., 1957. Pyroxenes from the early and middle stages of fractionation of the Skaergaard intrusion, East Greenland: Mineral. Mag., v. 31, p. 511-543.

Campbell, I.H. and Borley, G.D., 1974. The geochemistry of pyroxenes from the lower layered series of the Jimberlana intrusion, Western Australia: Contrib. Mineral. Petrol., v. 47 , p. $281-297$.

Colby, J.W., 1971. MAGIC IV-a new improved version of MAGIC: Sixth Natl. Conf. Electron Probe Analysis Proc.

Hess, H.H., 1960. Stillwater igneous complex, Montana: Geol. Soc. Am. Mem. 80.

Jaffe, H.W., Robinson, P., and Tracy, R.J., 1975. Orientation of pigeonite exsolution lamellae in metamorphic augite: Correlation with composition and calculated optimal phase boundaries: Am. Mineral., v. 60, p. 9-28.

Kretz, R., 1963. Distribution of magnesium and iron between orthopyroxene and calcic pyroxene in natural mineral assemblages: J. Geol., v. 71, p. 773-785.

Lindsley, D.H., King, Jr., H.H., and Turnock, A.C., 1974. Compositions of synthetic augite and hypersthene coexisting at $810^{\circ} \mathrm{C}$ : Application to pyroxenes from lunar highland rocks: Geophys. Res. Lett., v. 1, p. 134-136.

Muir, I.D. and Tilley, C.E., 1957. Contributions to the petrology of Hawaiian basalts. I. The picrite-basalts of Kilauea: Am. J. Sci., v. 255, p. 241-253.

Poldervaart, A. and Hess, H.H., 1951. Pyroxenes in the crystallization of basaltic magma: J. Geol., v. 59, p. 472489.

Reed, S.J.B. and Long, J.V.P., 1963. Electron probe measurements near phase boundaries. In Pattee, H.H., Cosslett, V.E., and Engström, A. (Eds.), X-ray optics and X-ray microanalysis: New York (Academic Press), p. 317-327. 



\section{PLATE 1}

Figures 1-3 Hypersthene gabbro from Site 334, Core 21, Section 1, sampled at $52-58 \mathrm{~cm}$.

1. Large orthopyroxene grain, lower third of picture, partly enclosing and occurring as rims on anhedral clinopyroxene crystals. Crossed nicols. 2. Subhedral orthopyroxene, upper right (exsolution lamellae not visible), and clinopyroxene, upper and lower left, exhibiting both (100) and (001) hypersthene exsolution lamellae. Crossed nicols. 3. Twinned clinopyroxene crystal containing both (100) and (001) hypersthene exsolution lamellae. Crossed nicols.

Figure 4 Hornblende gabbro from Site 334, Core 22, Section 1, sampled at 5-6 cm (\#1). Twinned plagioclase anhedra, altered clinopyroxene, and blocky deuteric amphibole forming a fine-grained intergranular mosaic between two large abraded plagioclase crystals. Crossed nicols. 
PLATE 1
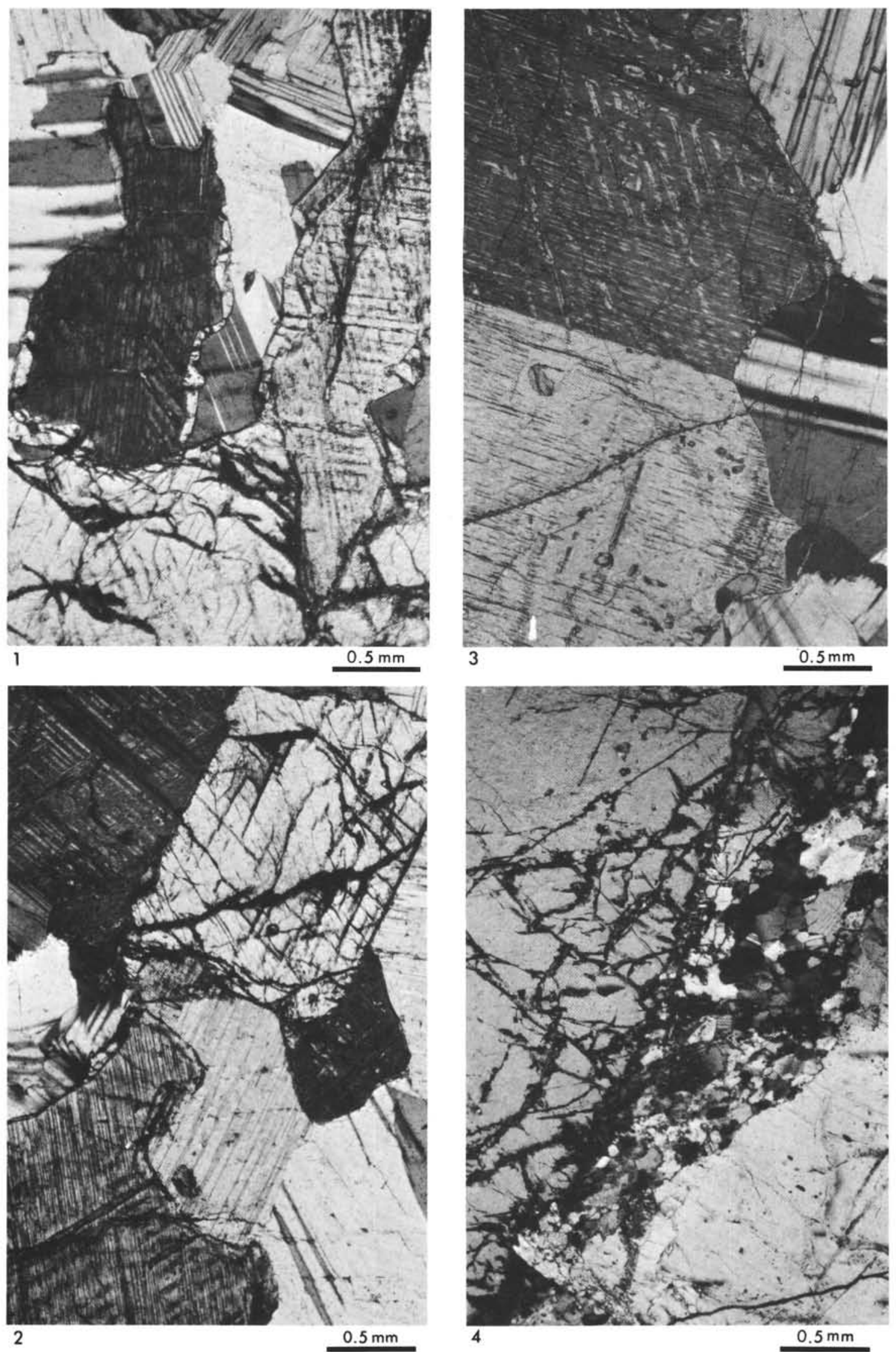


\section{PLATE 2}

Hypersthene gabbro from Site 334, Core 23, Section 1, sampled at 113-119 $\mathrm{cm}(\# 12)$.

Figure 1 A typical field of view under crossed nicols exhibiting anhedral clinopyroxene, upper left and lower right, partly mantled by secondary fibrous amphibole; anhedral orthopyroxene, center of picture, and plagioclase feldspar. Crossed nicols.

Figure 2 Orthopyroxene with coarse (001) exsolution lamellae, left side of picture. The (001) lamellae are not visible in this orientation. Clinopyroxene, right side of picture, containing coarse continuous (001) lamellae and fine discontinuous (100) lamellae of hypersthene. Crossed nicols. 
PLATE 2
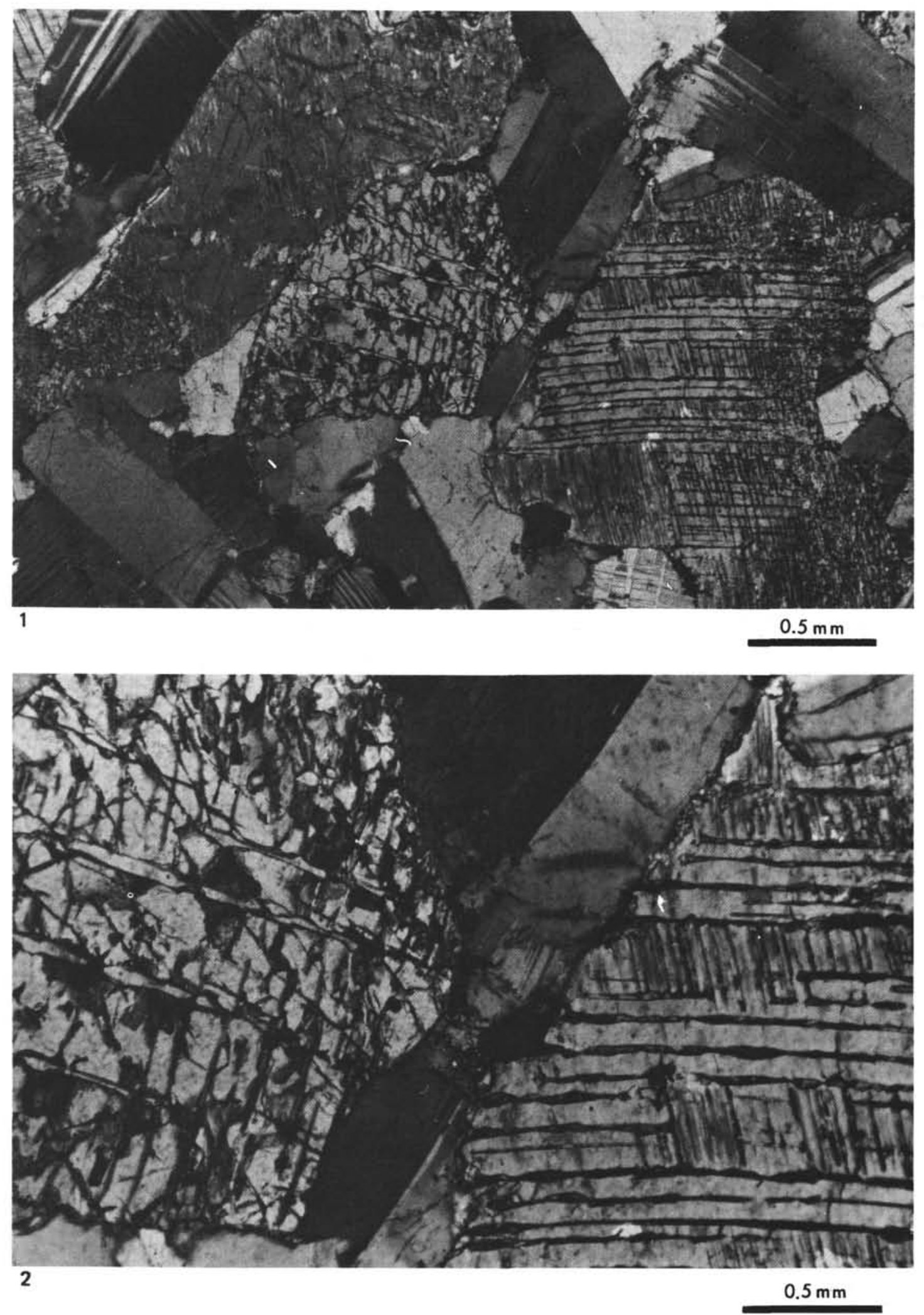